\title{
Meningkatkan AKTiVitas Belajar Matematika Siswa DenGan MengGunaKan Media Domat
}

\author{
Enhancing Students LEARning ACtivities USING Domat MEDiA
}

\author{
Imas Komariah $^{1}$ dan Rostina Sundayana ${ }^{2}$
}

1SMP Negeri 2 Tarogong Kidul

Garut, Jawa Barat, Indonesia

m45kmath@gmail.com

\author{
2Program Studi Pendidikan Matematika, STKIP Garut \\ Garut, Jawa Barat, Indonesia \\ sundayana.math@gmail.com
}

\begin{abstract}
Abstrak
Sebagian besar siswa SMP menganggap bahwa matematika merupakan mata pelajaran yang sulit dipelajari dan membosankan. Salah satu penyebabnya adalah karena matematika bersifat abstrak serta pemilihan metode pembelajaran yang kurang tepat. Hal ini menjadi tantangan bagi para guru matematika untuk dapat menggunakan media pembelajaran yang dapat melibatkan siswa secara aktif belajar matematika, sehingga para siswa merasa senang belajar matematika. Tujuan dari penelitian tindakan kelas ini adalah untuk mengetahui apakah penggunaan media permainan DOMAT dapat meningkatkan aktivitas belajar siswa kelas IX-A SMP Negeri 2 Tarogong Kidul. Adapun hasil penelitian ini adalah pada siklus I belum menunjukkan tercapainya indikator keberhasilan yang ditetapkan, yaitu jumlah siswa yang aktif sebanya $75 \%$ (27 orang). Artinya, pelaksanaan tindakan pada siklus pertama belum berhasil dan harus dilanjutkan ke siklus berikutnya dengan perbaikan tindakan yang dianggap menjadi penyebab ketidakberhasilan. Pada siklus II sudah menunjukkan tercapainya indikator keberhasilan yang sudah ditetapkan, yaitu jumlah siswa yang aktif pada setiap pertemuan $75 \%$. Artinya, pelaksanaan tindakan pada siklus II sudah berhasil. Dengan demikian dapat ditarik kesimpulan bahwa penggunaan media permainan domat merupakan salah satu cara atau strategi untuk meningkatkan aktivitas siswa dalam pembelajaran matematika.

Kata Kunci: Aktivitas belajar, Domino Matematika.
\end{abstract}

\begin{abstract}
Most junior high school students consider that math is a difficult subject to learn and bore. One reason is that mathematics is abstract and the choice of less precise learning method. It is a challenge for math teachers to be able to use instructional media that can involve students actively learning math, so that students feel happy learning math. The purpose of this classroom action research is to find out whether the use of DOMAT game media can improve the learning activity of grade IX-A students of SMP Negeri 2 Tarogong Kidul. The results of this study is that in cycle I has not shown the achievement of the established success indicators, ie the number of active students sebanya 75\% (27 people). That is, the implementation of the action in the first cycle has not been successful and should proceed to the next cycle with the improvement of the action considered to be the cause of the unsuccessfulness. In the second cycle has shown the achievement of a predetermined success indicator, ie the number of students who are active at each meeting $75 \%$. That is, the implementation of action in cycle II has been successful. Thus it can be concluded that the use of domat game media is one way or strategy to increase student activity in learning mathematics.

Keyword: Learning Activities, Domino Mathematics.
\end{abstract}

Jurnal "Mosharafa", Volume 6, Nomor 3, September 2017 


\section{Pendahuluan}

Hakekat matematika menurut Fowler (dalam Suyitno, 1985:736) yaitu "Mathematics is the abstract science of space and number." Matematika adalah ilmu yang abstrak berkenaan dengan ruang dan bilangan. Hal lain, Marshall Walker (dalam Sundayana, 2014:3) "Mathematics maybe difined as the study of abstract structures and their interrelations," matematika dapat didefinisikan sebagai studi tentang struktur-struktur abstrak dengan berbagai hubungannya. Dari kedua pendapat tersebut, menjelaskan bahwa matematika merupakah hal yang abstrak, berkenaan dengan ruang dan bilangan terdiri dari berbagai macam struktur yang saling berhubungan. Berkenaan dengan matematika yang bersifat abstrak tersebut, merupakan kesulitan tersendiri yang harus dihadapi siswa dalam mempelajari matematika. Tidak hanya siswa, guru pun mengalami kesulitan dalam mengajarkan metematika.

Kesulitan dalam mempelajari matematika harus diatasi sedini mungkin. Siswa yang mengalami kesulitan belajar matematika di tingkat sekolah dasar pada kelas bawah, maka akan mengalami kesulitan belajar pada kelas berikutnya atau jenjang sekolah lainnya. Salah satu upaya untuk mengatasi kesulitan belajar matematika tersebut adalah dengan cara menyajikan konsep-konsep matematika disajikan dalam bentuk konkrit. Kemudian diarahkan pada tahapan semi konkrit, dan pada akhirnya siswa dapat berfikir dan memahami matematika secara abstrak (Sundayana, 2014:28).

Untuk menyajikan konsep matematika secara konkrit, dapat dilakukan dengan menggunakan media pembelajaran. Pembelajaran yang menggunakan media yang tepat, akan membantu dapat menjembatani konsep matematika yang abstrak menjadi yang konkret. Kemp \& Dayton (1985: 43), menyatakan bahwa kontribusi media dalam pembelajaran adalah: 1) Penyampaian pembelajaran dapat lebih terstandar; 2) Pembelajaran dapat lebih menarik; 3) Waktu penyampaian pembelajaran dapat diperpendek; 4) Kualitas pembelajaran dapat ditingkatkan; 5) Proses pembelajaran dapat berlangsung kapanpun dan dimanapun diperlukan; 6) Sikap positif siswa terhadap materi pembelajaran serta proses pembelajaran dapat ditingkatkan; dan 7) Peran guru berubah kearah yang positif.

Berdasarkan pengalaman peneliti, munculnya kesulitan belajar matematika dipengaruhi pula dengan metode pembelajaran yang dipakai. Selain itu, siswa kurang terlibat dalam aktivitas belajar, guru telalu banyak mendominasi penyampaian konsep, sehingga siswa menjadi pasif dan bosan. Hal tersebut menjadi tantangan bagi para guru matematika untuk pandai-pandai memilih metode pembelajaran dan penggunaan media pembelajaran yang dapat membangkitkan aktivitas belajar matematika para siswa. Dengan metode pembelajaran yang tepat, para siswa 
merasa senang dan aktif belajar matematika. Salah satu metode yang dapat digunakan untuk meningkatkan aktivitas belajar siswa khususnya pada pelajaran matematika adalah dengan menggunakan metode permainan.

Terdapat berbagai jenis permainan yang ada disekitar lingkungan kita, salah satu permainan yang cukup dikenal luas oleh masyarakat adalah permainan domino. Permainan domino sering ditemui dan dimainkan oleh bapak-bapak untuk mengisi waktu luang, misalnya pada saat 'ronda malam'. Permainan domino merupakan permainan yang cukup mudah dimainkan cukup menghibur, dan murah meriah, serta dapat dimainkan oleh berbagai kalangan. Dari hal tersebut, peneliti mencoba menggunakan metode permainan domino dalam pembelajaran matematika, karena aturan yang ada pada permainan domino, ada kaitannya dengan aturan-aturan matematika.

Aturan permainan domino yang dimainkan oleh empat orang, yaitu setiap pemain harus memasangkan setiap kartu yang mempunyai banyak angka yang sama. Angka-angka (banyak bulatan) yang ada pada kartu domino, penulis modifikasi dengan soal-soal dari materi pelajaran yang dipelajari. Dengan permainan ini diharapkan dapat meningkatkan aktivitas siswa dalam kegiatan pembelajaran matematika. Oleh karena itu penulis melakukan penelitian tindakan kelas untuk meningkatkan aktivitas belajar siswa dengan menggunakan media DOMAT, yang merupakan singkatan dari 'DOmino MATematika'.

Mulyono (2001: 26), mengartikan aktivitas adalah "Kegiatan atau keaktifan". Segala sesuatu yang dilakukan atau kegiatan-kegiatan yang terjadi baik fisik maupun non-fisik, merupakan suatu aktivitas. Hal lain, Lebih lanjut, Sardiman (2011:100) mengemukakan bahwa aktivitas belajar dapat bersifat fisik maupun mental. Dalam proses belajar kedua aktivitas itu harus saling berkaitan.

Terdapat berbagai jenis aktivitas yang dapat dilakukan di dalam kelas. Djamarah dan Zain (2006:84) mengemukakan bentuk aktivitas belajar siswa, diantaranya berupa: 1) Siswa belajar secara individual untuk menerapkan konsep, prinsip dan generalisasi; 2) Siswa belajar dalam bentuk kelompok untuk memecah masalah; 3) Setiap siswa berpartisipasi dalam melaksanakan tugas belajarnya melalui berbagai cara. (4) Antar siswa terjalin hubungan sosial dalam melaksanakan kegiatan belajar; 5) Setiap siswa bisa mengomentari dan memberikan tanggapan terhadap pendapat siswa lainnya; dan 6) Setiap siswa berkesempatan menggunakan berbagai sumber belajar yang tersedia.

Pada permainan Domat, setiap siswa akan melakukan keenam aktivitas tersebut. Mulai aktivitas sendiri, yaitu membaca dan memahami kartu soal yang muncul, kemudian menyelesaikannya. Sementara siswa yang lainnya aktif ikut menyelesaikan masalah yang ada. Antar 
siswa terjalin saling komunikasi menanggapi jawaban teman-temannya.

Arisnawati dalam Saefudin (2012:3) metode permainan sebagai cara yang digunakan guru dalam menyajikan pelajaran dengan menciptakan suasana yang menyenangkan, serius tapi santai dengan tidak mengabaikan tujuan pelajaran yang hendak dicapai. Dalam melakukan permainan diperlukan alat permainan yang edukatif sehingga akan membuat permainan menjadi lebih menarik. Ciri-ciri alat permaian yang edukatif menurut (Tedjasaputra, 2007:81) adalah sebagai berikut:

1. dapat digunakan dalam berbagai cara, sehingga dapat mencapai bermacam-macam tujuan dan manfaat,

2. berfungsi untuk mengembangkan berbagai aspek perkembangan kecerdasan serta motorik anak,

3. membuat anak terlibat secara aktif, dan sifatnya konstruktif.

Dienes dalam Ruseffendi (1992:125127), konsep-konsep matematika akan berhasil jika dipelajari dalam tahap-tahap tertentu. Dienes membagi tahap-tahap belajar menjadi 6 tahap, yaitu :

1. Permainan bebas (free play)

2. Permainan yang menggunakan aturan (Games)

3. permainan kesamaan sifat (searching for communalitifies)

4. permainan representasi (representation)

5. permainan dengan simbol (symbolization)
6. permainan dengan formalisasi (formalization)

Dalam penelitian ini, tahap yang digunakan adalah tahap permainan yang menggunakan aturan (games) dan penelitian ini dilaksanakan di kelas IX-A SMP Negeri 2 Tarogong Kidul dengan materi pelajaran Statistika pada pokok bahasan Ukuran Pemusatan dan Ukuran Penyebaran Data.

Adapun langkah-langkah pembelajaran metode permainan dalam penelitian ini dilakukan berdasarkan Fandy dalam Saefudin (2012:3) sebagai berikut:

1. Guru menentukan topik atau materi permainan yang akan digunakan dalam pembelajaran yaitu materi pelajaran Statistika pada pokok bahasan Ukuran Pemusatan dan Ukuran Penyebaran Data;

2. Guru menyiapkan alat dan bahan yang diperlukan yaitu kartu domino matematika;

3. Guru menyusun petunjuk atau langkah-langkah pelaksanaan permainan;

4. Guru menjelaskan maksud dan tujuan serta aturan dalam permainan;

5. Siswa dibagi atas individu atau kelompok;

6. Siswa melakukan kegiatan permainan yang dipimpin oleh guru;

7. Siswa berhenti melakukan permainan dan melaporkan hasil dari permainan; 
Guru memberikan kesimpulan tentang pengertian atau konsep yang dimaksud dalam tujuan tersebut.

\section{Metode}

Dalam penelitian ini, penulis memilih jenis penelitian tindakan kelas yang dilaksanakan sebanyak dua siklus. Masingmasing siklus dimulai dari tahap perencanaan, pelaksanaan, dan pengamatan, sampai dengan refleksi. Sebelum melaksanakan penelitian, penulis melakukan langkah-langkah sebagai berikut:

\section{Perencanaan}

Kegiatan ini meliputi: a) Mengidentifikasi permasalahan dan menentukan rencana tindakan b) Mengumpulkan data awal melalui pengamatan; c) Membuat lembar observasi untuk melihat bagaimana suasana ketika belajar mengajar dilaksanakan; d) Membuat kuesioner untuk mengumpulkan data tentang tanggapan siswa mengenai pelaksanaan pembelajaran.

2. Pelaksanaan Tindakan

Tindakan yang telah dirancang, dilaksanakan oleh peneliti yang merupakan guru mata pelajaran matematika kelas IX SMP Negeri 2 Tarogong Kidul Kabupaten Garut. Pelaksanaan tindakan yaitu penggunaan metode permainan.

Sebelum pelaksanaan tindakan, siswa dikelompokkan menjadi 12 kelompok dengan masing-masing kelompok beranggotakan 3 orang. Dari 12 kelompok ini nantinya akan dibagi lagi menjadi 3 kelompok besar yang masing-masing terdiri dari 4 kelompok kecil.

Pembelajaran yang dilakukan guru menggunakan skenario pembelajaran yang telah dibuat, yaitu: 1) guru menjelaskan maksud/tujuan pembelajaran dan metode serta teknik yang akan digunakan; 2) guru membahas materi pelajaran dilanjutkan dengan tanya jawab; 3) Guru memberikan latihan soal dengan menggunakan media permainan DOMAT; 4) Ssetelah permainan selesai, guru memberi reward kepada kelompok yang memenangkan permainan; 5) Guru memberikan penjelasan singkat sekaligus menyampaikan kesimpulan; 6) Evaluasi dan refleksi.

\section{Observasi}

Observasi dilakukan dengan menggunakan lembar observasi yang telah dibuat. Proses observasi dilakukan oleh seorang guru sebagai observer untuk mengamati aktivitas guru dan siswa dalam kels selama melaksanakan tindakan dalam proses pembelajaran.

4. Refleksi

Hasil yang diperoleh pada setiap observasi dari siklus I dianalisis Kekurangan-kekurangan atau kelemahankelemahan yang terjadi pada siklus I akan diperbaiki pada siklus berikutnya. Tiap siklus dilaksanakan sesuai dengan perubahan yang ingin dicapai, yaitu jika jumlah siswa aktif (mengikuti proses pembelajaran) sebanyak $75 \%$ pada tiap pertemuan.

Adapun alur penelitian, disajikan pada gambar berikut: 


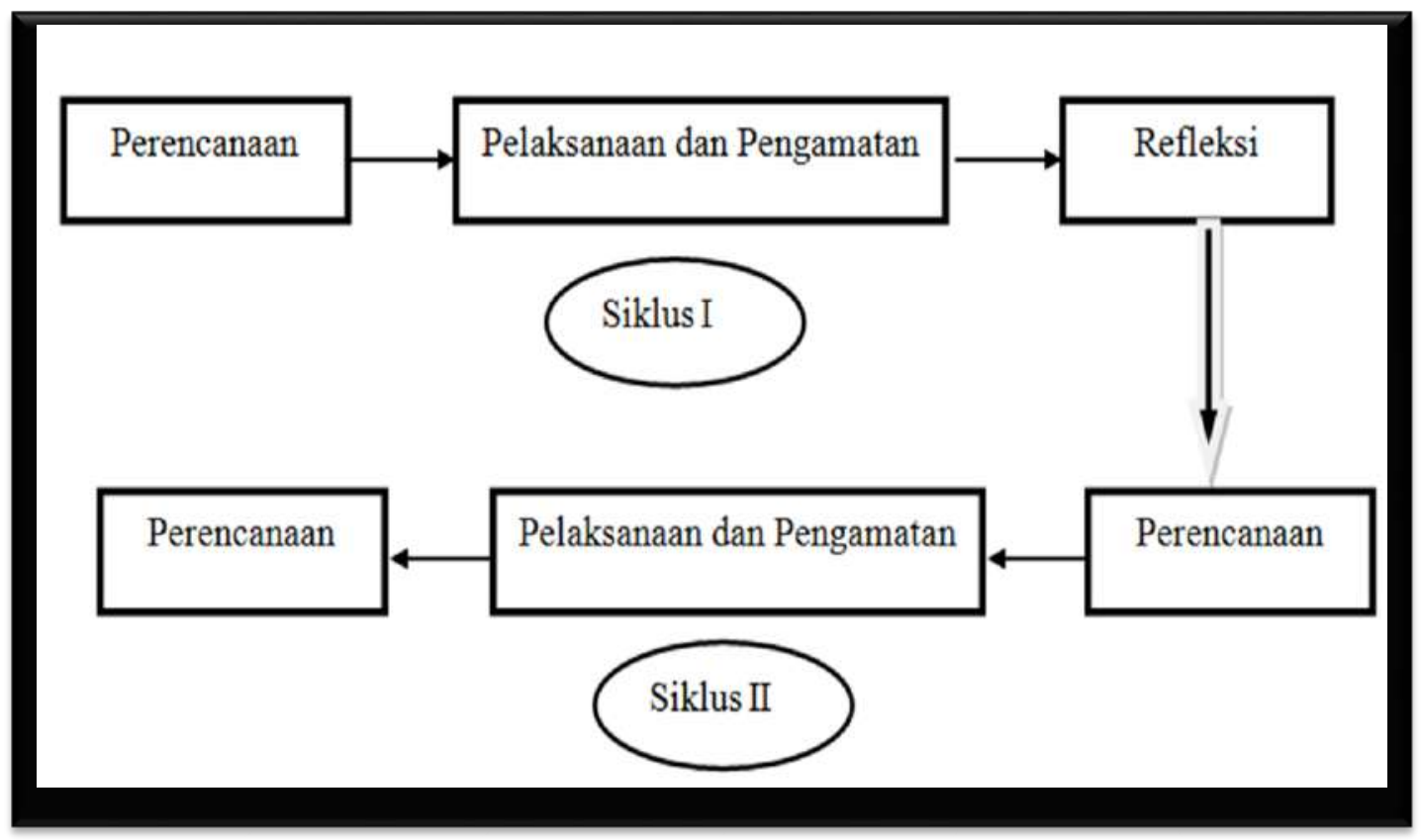

Gambar 1. Alur Penelitian.

Data kualitatif dikumpulkan dari hasil pengamatan dan hasil angket siswa. Langkah-langkah mengolah data kualitatif :

1) data yang terkumpul dibaca; 2) data diklasifikasikan kedalam dua kelompok, yaitu data yang positif dan data yang negatif; 3) mereduksi data yang negatif; 4) mendeskripsikan hasil dari data yang memberikan tanggapan positif.

\section{Hasil dan Pembahasan}

1. Pelaksanaan Siklus 1

Pelaksanaan pembelajaran siklus I terdiri dari 2 pertemuan yang dilaksanakan pada tanggal 5 dan 8 Oktober 2016. Materi pokok yang dibahas tentang ukuran gejala pemusatan data statistika yaitu mean, median, dan modus.

Pada pertemuan pertama guru menjelaskan tujuan pembelajaran yang ingin dicapai dan metode serta teknik yang digunakan. Selama kegiatan pembelajaran berlangsung, observer mengamati aktivitas guru dan siswa.

Setiap pertemuan berlangsung selama $2 \times 40$ menit, dimana 40 menit pertama pembahasan materi dan pada 40 menit kedua latihan soal dengan menggunakan media permainan domat.

Langkah berikutnya siswa diberi kuis untuk melihat pemahaman siswa dan di akhir pelajaran siswa diminta untuk membuat refleksi kegiatan yang sudah dilaksanakan. Tidak lupa guru memberikan reward kepada kelompok siswa yang berhasil memenangkan permainan domat.

2. Hasil Tindakan Siklus I

Berdasarkan hasil pengamatan yang dilaksanakan oleh pengamat pada tanggal 5 dan 8 Oktober 2015, diperoleh hasil analisis aktivitas kelompok siswa yang ditampilkan pada tabel berikut: 
Tabel 1.

Rekapitulasi Hasil Observasi terhadap Aktivitas Siswa Siklus I

\begin{tabular}{|lcc|}
\hline \multicolumn{1}{|l}{ Aspek-aspek yang diobservasi } & \multicolumn{2}{c}{$\begin{array}{c}\text { Jumlah siswa } \\
\text { pada pertemuan }\end{array}$} \\
\cline { 2 - 3 } & 1 & 2 \\
\hline $\begin{array}{l}\text { Guru menyampaikan materi, } \\
\text { siswa memperhatikan dengan } \\
\text { serius, bertanya, menjawab, } \\
\text { terlibat dalam permainan } \\
\text { domat }\end{array}$ & 20 & 24 \\
\hline
\end{tabular}

Berdasarkan data dari tabel diatas, dapat disimpulkan bahwa tindakan pada siklus I belum menunjukkan tercapainya indikator keberhasilan yang ditetapkan, yaitu jumlah siswa yang aktif sebanya $75 \%$ (27 orang). Artinya, pelaksanaan tindakan pada siklus pertama belum berhasil dan harus dilanjutkan ke siklus berikutnya dengan perbaikan tindakan yang dianggap menjadi penyebab ketidakberhasilan.

3. Refkeksi Hasil Tindakan Siklus I

Setelah melakukan diskusi dengan pengamat diperoleh kesimpulan bahwa kurang berhasilnya tindakan pada siklus pertama adalah masih terdapat siswa yang belum memahami permainan domat dan kurang kerjasama dengan teman sekelompoknya. Dari hasil refleksi tersebut, maka peneliti melakukan perbaikan tindakan pada siklus kedua.

\section{Pelaksanaan Siklus II}

Siklus kedua dilaksanakan pada tanggal 19 dan 22 Oktober 2016, dengan materi pokok yang dibahas tentang ukuran gejala penyebaran data statistika, yaitu jangkauan dan kuartil. Pelaksanaan tindakan pada siklus II pada dasarnya sama seperti siklus I, hanya dilakukan perbaikan- perbaikan sesuai dengan hasil refleksi dari siklus I.

Pada awal pertemuan diterangkan kembali teknik dan aturan pada permainan domat. Selain itu siswa diberi motivasi untuk selalu memperhatikan apa-apa yang disampaikan oleh guru, kemudian disuruh bertanya jika masih ada materi yang belum dimengerti agar dapat lebih memahami materi pelajaran yang dibahas.

5. Hasil Tindakan Siklus II

Berdasarkan hasil pengamatan yang dilaksanakan oleh pengamat pada tanggal 19 dan 22 Oktober 2016, diperoleh hasil analisis aktivitas kelompok siswa yang ditampilkan pada tabel berikut:

Tabel 2.

Rekapitulasi Hasil Observasi terhadap Aktivitas Siswa Siklus II

\begin{tabular}{lcc|}
\hline \multicolumn{1}{|l}{ Aspek-aspek yang diobservasi } & \multicolumn{2}{c}{$\begin{array}{c}\text { Jumlah siswa } \\
\text { pada pertemuan }\end{array}$} \\
\cline { 2 - 3 } & 1 & 2 \\
\hline $\begin{array}{l}\text { Guru menyampaikan materi, } \\
\text { siswa memperhatikan dengan } \\
\text { serius, bertanya, menjawab, } \\
\text { terlibat dalam permainan } \\
\text { domat }\end{array}$ & 28 & 32 \\
\hline
\end{tabular}

Berdasarkan data dari tabel 2 di atas dapat disimpulkan bahwa tindakan pada siklus II sudah menunjukkan tercapainya indikator keberhasilan yang sudah ditetapkan, yaitu jumlah siswa yang aktif pada setiap pertemuan 75\%. Artinya, pelaksanaan tindakan pada siklus II sudah berhasil.

\section{Refleksi Siklus II}

Dalam pelaksanaan siklus II sudah nampak aktivitas siswa dalam kegiatan pembelajaran, bahkan setelah selesai 
pembelajaran ada beberapa kelompok siswa yang mengisi waktu kosong pergantian jam pelajaran dengan memainkan permainan domat.

Hal-hal yang menyebabkan tercapainya peningkatan aktivitas siswa dalam kegiatan pembelajaran matematika adalah:

a. Siswa diberi penjelasan terlebih dahulu bahwa metode yang akan digunakan menggunakan media permainan yang menyenangkan dan murah meriah.

b. Guru terus menerus memberikan motivasi kepada siswa untuk terlibat aktif dalam kegiatan belajar.

c. Guru memberikan reward kepada siswa yang berhasil menyelesaikan permainan dengan cepat dan benar.

\section{Penutup}

Berdasarkan hasil penelitian dan pembahasan yang telah diuraikan pada bab sebelumnya, dapat ditarik kesimpulan bahwa penggunaan media permainan DOMAT dapat meningkatkan aktivitas belajar matematika siswa kelas IX-A SMP Negeri 2 Tarogong Kidul. Hal ini terlihat dengan adanya peningkatan jumpah siswa yang terlibat aktif dalam pembelajaran pada siklus I dan siklus II.

Pada pembelajaran dengan menggunakan media permainan DOMAT, pertama-tama tentu saja guru harus menyiapkan dahulu media yang akan digunakan, yaitu berupa kartu domino yang sudah dimodifikasi dengan soal-soal matematika. Selanjutnya guru menjelaskan aturan dan teknik dalam permainan DOMAT. Sebenarnya media DOMAT ini hanya digunakan untuk membantu siswa dalam mengerjakan soalsoal latihan setelah mengikuti proses pembelajaran seperti biasa, dan ternyata hasilnya dapat meningkatkan aktivitas siswa dalam pembelajaran matematika.

Berdasarkan kesimpulan di atas, peneliti merekomendasikan:

Pembelajaran dengan menggunakan media hendaknya terus dikembangkan; (2) Penggunaan media permainan DOMAT dapat dijadikan salah satu alternatif untuk meningkatkan aktivitas belajar siswa; (3) Menggunakan media permainan DOMAT pada materi pelajaran lain; dan (4) Senantiasa memberikan motivasi kepada siswa agar selalu terlibat aktif dalam pembelajaran.

\section{DAfTAR Pustaka}

Djamarah, S.B., Zain, A. (2006). Strategi Belajar Mengajar. Jakarta: Rineka Cipta.

Kemp, J.E. dan Dayton, D.K. (1985). Planning and producing instructional media (5th ed). New York: Harper \& Row Publisher Cambridge.

Mulyono, A.M. (2001). Kamus Besar Indonesia. Jakarta : Balai Pustaka

Ruseffendi, E. T. (1992). Pengantar Kepada Guru Mengembangkan Kompetensinya dalam Pengajaran Matematika untuk Meningkatkan CBSA. Bandung: Tarsito.

Saefudin, A. (2012). Penerapan Metode Permainan Menggunakan Kartu Kosakata dalam Pembelajaran Bahasa Inggris Siswa V SD. AbstrakPenelitian FKIP UNS Surakarta. Diakses dari: http://jurnal.fkip.uns.ac.id/index.php/ 
pgsdkebumen/article/view/284. [2

Oktober 2016]

Sardiman. (2011). Interaksi dan Motivasi

Belajar Mengajar. Jakarta: Bandung:

Refika Aditama.

Sundayana, R. (2014). Media dan Alat

Peraga dalam Pembelajaran

Matematika. Bandung: Alfabeta.

Suyitno, A. (2001). Pendidikan Matematika

I. Semarang : F Mipa Unnes

Tedjasaputra, M. (2007). Bermain Mainan

dan Permainan. Jakarta : Grasindo.

\section{Riwayat Hidup PENULIS}

Imas Komariah, S.Pd., M.Pd.

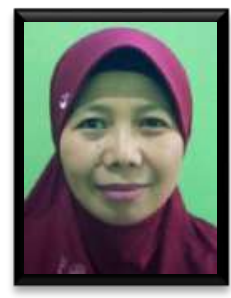

Lahir di Tasikmalaya, 10 Januari 1970. Staf pengajar di SMP N 2 Tarogong Kidul. S-1 Pendidikan Matematika IKIP Bandung, lulus tahun 1993. S2 Teknologi Pembelajaran, STKIP Garut, lulus tahun 2012.

\section{Drs. Rostina Sundayana, M.Pd.}

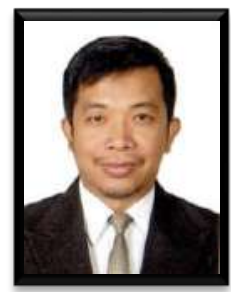

Lahir di Garut, 28 Desember 1966. Dosen Kopertis Wil. IV, dpk. STKIP Garut. S-1 Pendidikan Matematika IKIP Bandung, lulus tahun 1992. S2 Pendidikan Matematika UPI, Bandung, lulus tahun 2010. S3 Pendidikan Matematika UPI, Bandung, sampai sekarang. 
This page is intentionally left blank 